\title{
Determinan Price to Book Value Perusahaan Manufaktur
}

\author{
Abdurrakhman ${ }^{1}$ \\ ${ }^{1}$ Universitas Pancasila, Jl. Srengseng Sawah, Jagakarsa, Jakarta Selatan 12640
}

I N F O A R T I K E L

JEL Classification:

M40

016

\section{Keywords:}

current ratio,

return on equity,

total assets turnover,

size, price to book value.

\section{A B S T R A C T}

This study is aimed to test the influence of Current ratio (CR), Return on equity (ROE), Total assets turnover (TATO), and Size towards Price to book value (PBV). Samples are 114 firm firm years data of consumer goods listed companies in Indonesia Stock Exchange (IDX) during the period of 2006-2011 Analysis technique of data used multi linear regression of ordinary least square. This indicate that the available data has fulfilled the prerequisite to use multi-linier regression model. This research demonstrated that ROE and Size partially have significant influence towards the PBV. On the contrary, CR and TATO partially have no significant influence towards PBV. Simultaneously, $C R, R O E, T A T O$, and the size has significant influence towards PBV of Consumer goods companies in IDX during the period of 2006.

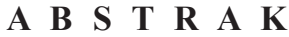

Penelitian ini bertujuan untuk menguji pengaruh Rasio Current (CR), Return on equity (ROE), Total omset aset (TATO), dan Ukuran menuju Harga terhadap nilai buku (PBV). Sampel adalah 114 data tahun perusahaan consumer goods di Bursa Efek Indonesia (BEI) tercatat selama periode 20062011. Teknik analisis data menggunakan regresi linier multi biasa setidaknya persegi. Ini menunjukkan bahwa data yang tersedia telah memenuhi syarat untuk menggunakan model regresi multi-linier. Penelitian ini menunjukkan bahwa ROE dan Ukuran parsial memiliki pengaruh yang signifikan terhadap PBV. Sebaliknya, CR dan TATO sebagian tidak memiliki pengaruh yang signifikan terhadap PBV. Secara bersamaan, CR, ROE, TATO, dan ukuran memiliki pengaruh signifikan terhadap PBV perusahaan barang konsumen di BEI selama periode 2006.

\section{Pendahuluan}

Keputusan investasi saham di pasar modal mengharuskan investor berhati-hati dalam pengambilan keputusan investasi dengan memahami informasi yang berhubungan dengan perusahaan yang menerbitkan saham.
Investor perlu melakukan berbagai analisis, baik analisis fundamental maupun analisis teknis. Agar laporan keuangan menjadi lebih berarti sehingga dapat dipahami dan dimengerti oleh berbagai pihak, baik manajemen, kreditor maupun investor, perlu dilakukan analisis 
laporan keuangan. Tujuan utama analisis laporan keuangan adalah agar mengetahui posisi keuangan dan kinerja perusahaan pada masa lalu, saat ini dan dapat pula untuk memprediksi kinerja perusahaan masa yang akan datang. Ukuran yang sering digunakan dalam analisis laporan keuangan adalah rasio keuangan yang dapat menjelaskan berbagai hubungan dan indikator keuangan. Beberapa rasio keuangan yang dikenal diantaranya: rasio likuiditas, rasio aktivitas, rasio profitabilitas, dan rasio solvabilitas (leverage ratio).

Bagi emiten, menjaga dan meningkatkan kinerja keuangan adalah suatu keharusan agar saham yang sudah diperdagangkan di bursa efek (go public) tetap eksis dan tetap diminati investor. Dalam melakukan keputusan investasi, investor juga memerlukan informasi tentang penilaian saham. Menurut Jogiyanto (2008:117) terdapat tiga jenis penilaian yang berhubungan dengan saham, yaitu nilai buku (book value), nilai pasar (market value) dan nilai intrinsik (intrinsic value). Salah satu pendekatan dalam menentukan nilai intrinsik saham (nilai sebenarnya) adalah price to book value (PBV). PBV atau rasio harga per nilai buku merupakan hubungan antara harga pasar saham dengan nilai buku per lembar saham. PBV merupakan salah satu indikator penilaian mengenai kondisi perusahaan yang go public di Bursa Efek Indonesia, termasuk pula perusahaanperusahaan Consumer Goods. Berdasarkan data dari tahun 2006 sampai dengan tahun 2011, PBV rata-rata perusahaan Consumer Goods yang terdaftar di Bursa Efek Indonesia tampak pada Gambar 1.

Berdasarkan Gambar di atas tampak bahwa Price to Book Value (PBV) rata-rata perusahaan Consumer Goods selama tahun 2006 sampai tahun 2011 mengalami kenaikan dan penurunan yang cukup signifikan atau dengan kata lain terdapat fenomena gap, di mana PBV rata-rata mengalami kenaikan dari 2.05 pada tahun 2006 menjadi 3.08 di tahun 2007 (+50\%), namun menurun di tahun 2008 menjadi sebesar $1.46(-52 \%)$ dibandingkan dengan tahun 2007. Selanjutnya, PBV rata-rata mengalami kenaikan yang sangat signifikan di tahun 2009 menjadi $3.76(+158 \%)$ dibandingkan tahun 2008, jauh di atas persentase kenaikan di tahun 2007. Di tahun 2010, PBV rata-rata mengalami kenaikan menjadi 4.10 atau hanya sebesar 9\% dibandingkan tahun 2009. Selanjutnya, PBV rata-rata mengalami kenaikan yang sangat signifikan di tahun 2011 menjadi 8.81 atau mengalami kenaikan sebesar 115\% dibandingkan tahun 2010.

Besarnya Price to book value (PBV) rata-rata dibandingkan dengan rata-rata Current ratio (CR), Return on equity (ROE), Total assets turnover (TATO), dan Size untuk perusahaan Consumer Goods yang terdaftar di Bursa Efek Indonesia selama periode tahun 2006 sampai dengan tahun 2011 dapat dilihat dalam Tabel 1.

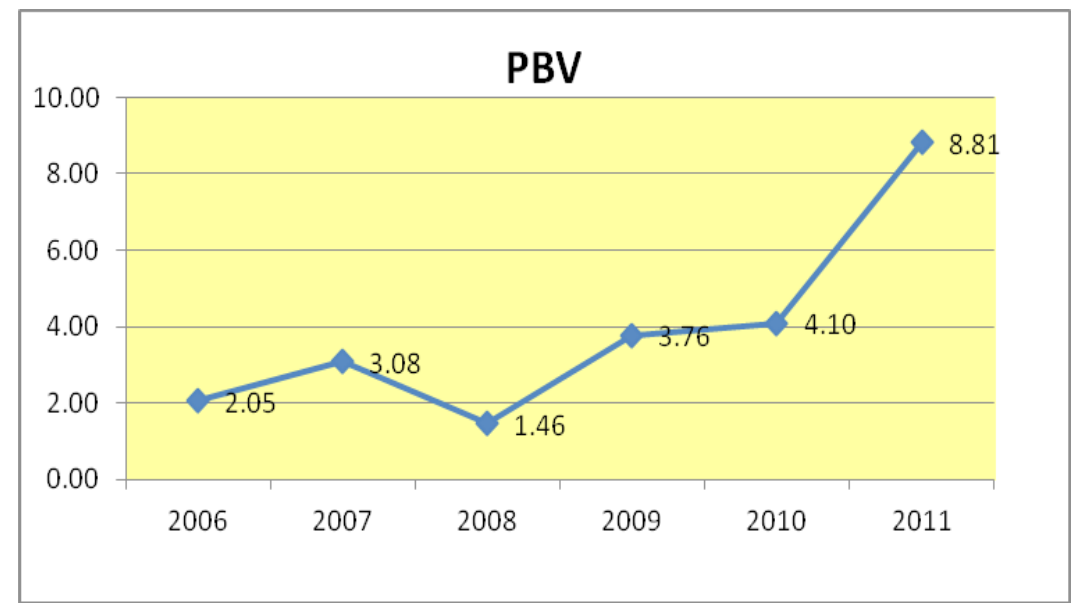

Gambar 1. Price to book value (PBV) rata-rata Perusahaan

Consumer Goods Tahun 2006 - 2011 
Tabel 1. Statistik Deskriptif Variabel Penelitian

\begin{tabular}{lccccccccccc}
\hline Variabel & & & \multicolumn{10}{c}{ Tahun (\%) } \\
& $\mathbf{2 0 0 6}$ & $\mathbf{\%}$ & $\mathbf{2 0 0 7}$ & $\mathbf{\%}$ & $\mathbf{2 0 0 8}$ & $\mathbf{\%}$ & $\mathbf{2 0 0 9}$ & $\mathbf{\%}$ & $\mathbf{2 0 1 0}$ & $\mathbf{\%}$ & $\mathbf{2 0 1 1}$ \\
\hline PBV & $\mathbf{2 . 0 5}$ & 50 & 3.08 & -53 & $\mathbf{1 . 4 6}$ & 158 & $\mathbf{3 . 7 6}$ & 9 & $\mathbf{4 . 1 0}$ & 115 & $\mathbf{8 . 8 1}$ \\
CR & 2.85 & 15 & 3.28 & 14 & 3.74 & 71 & 6.39 & -27 & 4.66 & -33 & 3.13 \\
ROE & 0.21 & -32 & 0.14 & 7 & 0.15 & 45 & 0.22 & -15 & 0.18 & 35 & 0.25 \\
TATO & 1.17 & 4 & 1.22 & 12 & 1.37 & -2 & 1.34 & -3 & 1.30 & 6 & 1.38 \\
SIZE & 2.474 & 22 & 3.016 & 18 & 3.551 & 12 & 3.994 & 21 & 4.834 & 10 & 5.336 \\
\hline
\end{tabular}

Sumber : Data Bursa Efek Indonesia yang diolah

Tabel 1 menunjukkan bahwa kenaikan atau penurunan current ratio, return on equity, total assets turnover, dan size perusahaan tidak selalu diikuti dengan kenaikan dan penurunan dengan tingkat yang sama terhadap PBV. Oleh karena itu, penulis ingin melihat sampai sejauh mana pengaruh current ratio, return on equity, total assets turnover, dan size perusahaan (diproksikan dengan total assets) yang merupakan faktor fundamental perusahaan tersebut terhadap Price to book value (PBV). Alasan PBV sebagai variabel dependen dikarenakan PBV mempunyai peran penting sebagai suatu pertimbangan bagi investor untuk memilih saham yang akan dibeli dan PBV dapat dijadikan sebagai indikator harga atau nilai saham (Ahmed dan Nanda, 2004 dalam Hidayati, 2010). Namun, PBV yang terlalu tinggi akan berisiko dan tidak menghasilkan return. PBV sangat terkait dengan return saham karena perubahan harga saham akan merubah besarnya rasio $\mathrm{PBV}$.

\section{Telaah Teori dan Pengembangan Hipotesis}

Signalling theory merupakan penjelasan dari asimetri informasi. Asimetri informasi adalah kondisi dimana suatu pihak memiliki informasi yang lebih banyak daripada pihak lain. Misalnya, pihak manajemen perusahaan memiliki informasi yang lebih banyak dibandingkan dengan pihak investor di pasar modal. Informasi yang diterima tersebut dapat direspons secara berbeda oleh investor. Perusahaan yang memiliki kondisi fundamental yang terpercaya dapat dibedakan dari perusa- haan yang memiliki kondisi fundamental kurang terpercaya dengan mengirimkan sinyal ke pasar modal. Sinyal dari perusahaan yang kondisi fundamentalnya terpercaya tentu akan direspons oleh investor, sehingga sinyal tersebut menjadi berkualitas. Sedangkan sinyal yang dikirim oleh perusahaan yang kondisi fundamentalnya kurang terpercaya tentu tidak akan dapat menyamai sinyal yang dikirim oleh perusahaan yang kondisi fundamentalnya terpercaya (Bhattacharya \& Dittmar, 2001 dalam Hendrawijaja, 2009).

Manajer pada umumnya termotivasi untuk menyampaikan informasi yang baik mengenai kondisi perusahaan kepada masyarakat luas karena melalui penyampaian informasi tersebut dapat meyakinkan masyarakat untuk menanamkan modalnya di perusahaan tersebut. Pihak luar tentunya hanya memiliki informasi yang minimal mengenai kebenaran dari informasi yang disampaikan tersebut. Jika manajer dapat memberikan sinyal yang meyakinkan kepada publik (tentunya harus didukung oleh data yang mendasarinya), maka publik juga akan merespons secara positif.

\section{Pengaruh Current ratio (CR) terhadap Price to book value (PBV)}

Current ratio (Rasio lancar) yaitu untuk mengukur kemampuan perusahaan dalam membayar kewajiban jangka pendek atau utang yang segera jatuh tempo. Dengan kata lain, seberapa banyak aktiva lancar yang tersedia untuk menutupi kewajiban jangka pendek yang segera jatuh tempo. Semakin tinggi current ratio suatu 
perusahaan berarti semakin kecil risiko kegagalan perusahaan dalam memenuhi kewajiban jangka pendeknya. Akibatnya, risiko yang ditanggung perusahaan juga semakin kecil. Dengan semakin kecilnya risiko yang ditanggung perusahaan maka diharapkan akan meningkatkan minat para investor untuk menanamkan dananya dalam perusahaan tersebut, sehingga investor lebih menyukai current ratio yang tinggi dibandingkan current ratio yang rendah. Berdasarkan pada uraian mengenai pengaruh current ratio terhadap price to book value, maka dapat dirumuskan hipotesis sebagai berikut:

$\mathrm{H}_{1}$ : Current ratio $(C R)$ berpengaruh signifikan terhadap Price to book value (PBV).

\section{Pengaruh Return on equity terhadap Price to book value (PBV)}

Return on equity (ROE) merupakan rasio untuk mengukur laba bersih sesudah pajak dengan modal sendiri. Return on equity merupakan salah satu rasio yang digunakan untuk menilai kinerja perusahaan. ROE yang semakin besar menggambarkan kinerja perusahaan yang semakin baik dan para pemegang saham akan mendapatkan keuntungan dari dividen yang diterima. Rasio ini juga menunjukkan efisiensi atas penggunaan modal sendiri. ROE yang semakin tinggi akan meningkatkan daya tarik investor untuk menanamkan dananya ke dalam perusahaan sehingga harga saham akan relatif meningkat, dan dengan demikian dapat meningkatkan PBV. Adanya daya tarik tersebut berdampak pada para investor dan calon investor untuk memiliki saham perusahaan semakin meningkat.

Hal ini sejalan dengan pendapat dari Robert Ang (1997) yang menyatakan bahwa keuntungan perusahaan yang semakin meningkat memberikan tanda bahwa kekuatan operasional dan keuangan perusahaan semakin membaik, sehingga memberikan pengaruh positif terhadap ekuitas. Berdasarkan pada uraian mengenai pengaruh Return on equity (ROE) terhadap Price to book value $(P B V)$, maka dapat dirumuskan hipotesis sebagai berikut:
$\mathrm{H}_{2}$ : Return on equity (ROE) berpengaruh signifikan terhadap Price to book value (PBV).

\section{Return on equity (ROE) berpengaruh signifikan terhadap Price to book value (PBV).}

TATO merupakan salah satu rasio aktivitas yang menunjukkan kemampuan serta efisiensi perusahaan dalam memanfaatkan aktiva yang dimilikinya atau perputaran aktiva-aktiva tersebut. Oleh karena itu, TATO dapat digunakan untuk mengukur seberapa efisiennya seluruh aktiva perusahaan dalam menunjang penjualan (Ang, 1997). Nilai rasio TATO yang tinggi menunjukkan semakin efisien suatu perusahaan dalam memanfaatkan aktiva yang dimilikinya dan menunjukkan semakin besar penjualan yang dihasilkan. Berdasarkan pada uraian mengenai pengaruh Total assets turnover (TATO) terhadap Price to book value (PBV), maka dapat dirumuskan hipotesis sebagai berikut:

$\mathrm{H}_{3}$ : Total assets turnover (TATO) berpengaruh signifikan terhadap Price to book value (PBV).

\section{Pengaruh Size terhadap Price to book value (PBV).}

Size (ukuran) perusahaan adalah skala besar kecilnya perusahaan yang ditentukan oleh beberapa hal antara lain total penjualan, total aktiva, dan rata-rata tingkat penjualan perusahaan. Suatu perusahaan besar yang sudah mapan akan memiliki akses yang mudah menuju pasar modal, sementara perusahaan yang baru dan yang masih kecil akan mengalami banyak kesulitan untuk memiliki akses ke pasar modal. Karena kemudahan akses ke pasar modal cukup berarti untuk fleksibilitas dan kemampuannya untuk memperoleh dana yang lebih besar, sehingga perusahaan mampu memiliki rasio pembayaran dividen yang lebih tinggi daripada perusahaan kecil (Chang dan Rhee, 1990 dalam Fira Puspita 2009).

Size perusahaan mempunyai pengaruh yang berbeda dengan nilai perusahaan. Dalam penelitian ini, size perusahaan dilihat dari pertumbuhan total assets yang dimiliki oleh perusahaan setiap tahunnya yang 
dapat dipergunakan untuk kegiatan operasi perusahaan. Jika perusahaan memiliki total assets yang semakin besar setiap tahunnya, pihak manajemen lebih leluasa dalam mempergunakan asset yang ada di perusahaan tersebut. Jika dilihat dari sisi manajemen, kemudahan yang dimilikinya dalam mengendalikan perusahaan akan meningkatkan nilai perusahaan. (Michell Suharli, 2006 dalam Hidayati, 2010).

Berdasarkan pada uraian mengenai pengaruh size terhadap Price to book value $(P B V)$, maka dapat dirumuskan hipotesis sebagai berikut:

$\mathrm{H}_{4}$ : Size berpengaruh signifikan terhadap Price to book value (PBV).

\section{Pengaruh Current ratio (CR), Return on equity (ROE), Total assets turnover (TATO), dan Size terhadap Price to book value (PBV).}

Current ratio (CR), Return on equity (ROE), Total assets turnover (TATO), dan Size perusahaan merupakan bagian dari faktor fundamental perusahaan yang umumnya digunakan untuk mengukur kinerja perusahaan. Semakin baik Current ratio (CR), Return on equity (ROE), Total assets turnover (TATO), dan Size menunjukkan kinerja perusahaan yang semakin baik pula. Hal ini dapat menjadi acuan bagi investor untuk menanamkan modalnya pada suatu perusahaan.
Berdasarkan pada uraian mengenai pengaruh Current ratio, Return on equity, Total assets turnover, dan Size terhadap Price to book value $(P B V)$, maka dapat dirumuskan hipotesis sebagai berikut:

$\mathrm{H}_{5}$ : Current ratio, Return on equity, Total assets turnover, dan Size secara simultan berpengaruh secara signifikan terhadap Price to book value $(P B V)$.

\section{Metode}

Penelitian ini merupakan riset kuantitatif dengan menggunakan sumber data sekunder. Sumber data diperoleh dari dari berbagai sumber, antara lain Bursa Efek Indonesia (www.idx.co.id) dan ICMD (Indonesia Capital Market Directory). Data yang digunakan merupakan gabungan antara data time series and cross section.

Populasi yang digunakan dalam penelitian ini adalah seluruh perusahaan Consumer Goods yang tercatat di Bursa Efek Indonesia (BEI) dengan tahun pengamatan dari tahun 2006 sampai dengan tahun 2011. Teknik penentuan sampel yang digunakan dalam penelitian ini adalah purposive sampling. Kriteria-kriteria dan seleksi sampel penelitian sebagaimana Tabel 2.

Tabel 2. Seleksi sampel

\begin{tabular}{lc}
\hline \multicolumn{1}{c}{ Keterangan } & Perusahaan \\
\hline $\begin{array}{l}\text { Perusahaan Consumer Goods yang terdaftar di BEI (Populasi Penelitian) di tahun } \\
2011\end{array}$ & 34 \\
Laporan keuangan tidak tersedia selama enam tahun berturut-turut, dari tahun 2006 & -4 \\
sampai dengan tahun 2011 & -1 \\
Perusahaan yang sama tetapi memiliki code yang berbeda, karena adanya preferred & -10 \\
stock & 19 \\
Sebagai Outlier atas data secara keseluruhan & 114 \\
Perusahaan yang terpilih menjadi sampel & 19 \\
Jumlah data diolah selama periode penelitian & \\
\hline
\end{tabular}


Metode analisis yang digunakan untuk menguji hipotesis adalah regresi linier berganda sebagai berikut:

$\mathrm{Y}=\alpha+\beta_{1} \mathrm{CR}+\beta_{2} \mathrm{ROE}+\beta_{3}$ TATO $+\beta_{4}$ LnSIZE $+\varepsilon$

dimana dalam hal ini:

$$
\begin{array}{ll}
\mathrm{Y} & =\begin{array}{l}
\text { Price to Book Value } \\
(\text { PBV })
\end{array} \\
\alpha & =\text { Konstanta } \\
\beta_{1}-\beta_{6} & =\text { Koefisien regresi } \\
\mathrm{CR} & =\text { Current assets } \\
\mathrm{ROE} & =\text { Return on equity } \\
\mathrm{TATO} & =\text { Total assets turnover } \\
\text { LnSIZE } & =\text { LnSize } \\
\varepsilon & =\text { Error }
\end{array}
$$

Definsi oprasional dan pengukuran variable sebagaimana terangkum pada Tabel 3.

\section{Hasil Penelitian dan Pembahasan}

Berdasarkan kriteria purposive sampling sebagaimana yang dijelaskan di Bab III, maka diperoleh jumlah sampel penelitian yang sesuai dengan kriteria adalah sebanyak 19 perusahaan. Dengan periode penelitian selama 6 tahun

\begin{tabular}{|c|c|c|c|c|c|}
\hline No. & Variabel & Definisi & Pengukuran & Skala & Sumber \\
\hline 1 & Current ratio $-\mathrm{CR}\left(\mathrm{X}_{1}\right)$ & $\begin{array}{l}\text { rasio untuk mengukur } \\
\text { kemampuan perusahaan } \\
\text { dalam membayar } \\
\text { kewajiban jangka pendek } \\
\text { atau utang yang segera } \\
\text { jatuh tempo }\end{array}$ & $\frac{\text { Current assets }}{\text { Current liabilities }}$ & Rasio & Rose et. al \\
\hline 2 & $\begin{array}{l}\text { Return on equity }-\mathrm{ROE} \\
\qquad\left(\mathrm{X}_{2}\right)\end{array}$ & $\begin{array}{l}\text { rasio untuk mengukur } \\
\text { laba bersih sesudah pajak } \\
\text { dengan modal sendiri. } \\
\text { Rasio ini menunjukkan } \\
\text { efisiensi penggunaan modal } \\
\text { sendiri }\end{array}$ & $\frac{\text { Net income }}{\text { Equity }}$ & Rasio & Rose et. al \\
\hline 3 & $\begin{array}{c}\text { Total assets turnover - } \\
\text { TATO }\left(\mathrm{X}_{3}\right)\end{array}$ & $\begin{array}{l}\text { rasio yang digunakan untuk } \\
\text { mengukur perputaran } \\
\text { semua aktiva yang dimiliki } \\
\text { perusahaan dan mengukur } \\
\text { berapa jumlah penjualan } \\
\text { yang diperoleh dari aktiva } \\
\text { dalam suatu periode }\end{array}$ & $\begin{array}{c}\underline{\text { Sales }} \\
\text { Total assets }\end{array}$ & Rasio & Rose et. al \\
\hline 4 & LnSize $\left(\mathrm{X}_{4}\right)$ & Total asset perusahaan & LnSize & Rasio & Rose et. al \\
\hline 5 & Price to book value $(\mathrm{Y})$ & $\begin{array}{l}\text { menunjukkan seberapa } \\
\text { jauh suatu perusahaan } \\
\text { mampu menciptakan nilai } \\
\text { perusahaan yang relatif } \\
\text { terhadap jumlah modal } \\
\text { yang diinvestasikan }\end{array}$ & $\begin{array}{l}\frac{\text { Market value per }}{\text { share }} \\
\text { Book value per } \\
\text { share }\end{array}$ & Rasio & Rose et. al \\
\hline
\end{tabular}
dari tahun 2006 sampai dengan tahun 2011, maka diperoleh data penelitian sebanyak 114 data, sebagaimana tampak di tabel berikut ini. Berdasarkan olah data dengan menggunakan SPSS, hasil analisis deskriptif pada Tabel 4.

Tabel 3. Definisi Operasional dan Pengukuran Variabel Penelitian 
Tabel 4. Deskripsi Variabel Penelitian

\begin{tabular}{lccccc}
\hline \multicolumn{1}{c}{ Variabel } & $\mathbf{N}$ & Mininum & Maximum & Mean & Std. Deviation \\
\hline PBV & 114 & .17 & 6.01 & 1.5822 & 1.25452 \\
CR & 114 & .90 & 17.61 & 3.5132 & 2.70187 \\
ROE & 114 & -.25 & .57 & .1198 & .10731 \\
TATO & 114 & .40 & 2.96 & 1.2682 & .44850 \\
LnSIZE & 114 & 20.36 & 31.61 & 27.5645 & 1.81344 \\
\hline
\end{tabular}

Sumber : Data Bursa Efek Indonesia yang diolah

Berdasarkan hasil pengujian diketahui untuk variabel PBV, jumlah data 114 , nilai minimum sebesar 0.17 , nilai maksimum sebesar 6.01, rata-rata sebesar 1.5822, dan deviasi standar sebesar 1.25452. Variabel CR (Current ratio) memiliki nilai minimum sebesar 0.90 , nilai maksimum sebesar 17.61, rata-rata 3.5132, dan deviasi standar sebesar 2.70187. Selanjutnya, variabel ROE (Return on equity) memiliki nilai minimum sebesar -0.25 , nilai maksimum sebesar 0.57 , rata-rata 0.1198 , dan standar deviasi sebesar 0.10731. Variabel TATO (Total assets turnover) memiliki nilai minimum sebesar 0.40 , nilai maksimum sebesar 2.96, rata-rata 1.2682 , dan standar deviasi sebesar 0.44850. Sedangkan variabel LnSize memiliki nilai minimum sebesar 20.36, nilai maksimum sebesar 31.61, rata-rata 27.5645, dan standar deviasi sebesar 1.81344.

Untuk memperoleh hasil pengujian yang baik, maka semua data yang dibutuh- kan dalam penelitian ini harus diuji terlebih dahulu agar tidak melanggar asumsi klasik yang ada. Sehingga hasil pengujian hipotesis yang dilakukan dapat dipertanggungjawabkan kebenaran secara tegas dan nyata. Pengujian asumsi klasik yang dilakukan pada penelitian ini meliputi uji normalitas, multikolinearitas, autokorelasi, dan heteroskedastisitas.

Berdasarkan olah data dengan menggunakan SPSS, hasil uji normalitas dengan menggunakan analisis grafik, tampak pada Gambar 2.

Dari Grafik Normal Probability Plot tampak bahwa titik-titik menyebar mengikuti garis diagonal, maka dapat disimpulkan bahwa data residual terdistribusi dengan normal.

Hasil Uji Multikolinieritas.

Berdasarkan olah data dengan menggunakan SPSS, hasil uji multikolinieritas, tampak pada Tabel 5.

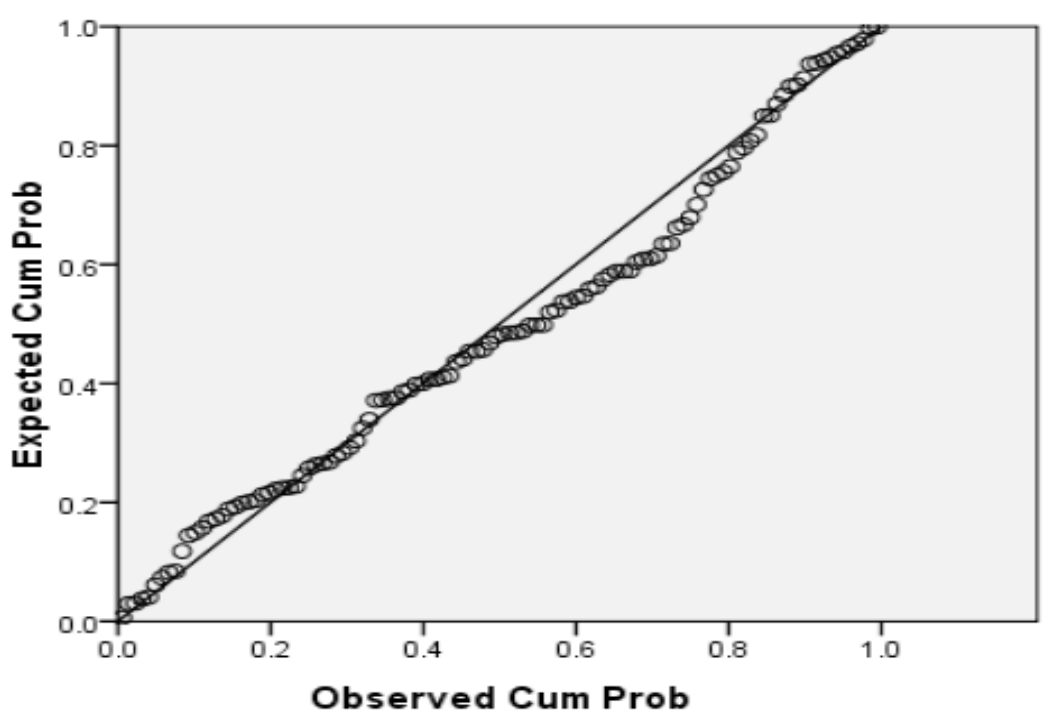

Gambar 2. Normal Probability Plot 
Tabel 5. Uji Multikolinieritas

\begin{tabular}{cccl}
\hline $\begin{array}{c}\text { Variabel } \\
\text { Independen }\end{array}$ & Tolerance & VIF & Keterangan \\
\hline CR & 0.791 & 1.264 & Tidak ada Multikolinieritas \\
ROE & 0.786 & 1.272 & Tidak ada Multikolinieritas \\
TATO & 0.888 & 1.126 & Tidak ada Multikolinieritas \\
LnSIZE & 0.856 & 1.169 & Tidak ada Multikolinieritas \\
\hline
\end{tabular}

Sumber : Data Bursa Efek Indonesia yang diolah

Suatu model regresi dinyatakan bebas dari multikolinearitas adalah jika mempunyai nilai Tolerance di atas 0.10 dan nilai VIF dibawah 10. Dari tabel di atas dapat diketahui bahwa nilai Tolerance untuk variabel independen CR, ROE, TATO, dan LnSIZE lebih dari 0.10 dan VIF kurang dari 10. Maka dapat disimpulkan bahwa variabel independen CR, ROE, TATO dan LnSIZE tidak memiliki masalah multikolinieritas.

Pengujian heteroskedatisitas dilakukan dengan metode grafik. Berdasarkan olah data dengan menggunakan SPSS, hasil uji heteroskedastisitas dengan menggunakan analisis grafik, tampak pada Gambar 3. bawah angka 0 pada sumbu $\mathrm{Y}$, maka tidak terjadi heteroskedastisitas.

Uji autokorelasi dilakujkan dengan Uji Durbin-Watson (DW). Nilai DW yang dihasilkan dari model regresi adalah 1.632. Sedangkan dari tabel DW diperoleh nilai $d_{\mathrm{L}}$ $=$ sebesar 1.6227, dan $d_{\mathrm{U}}$ sebesar 1.7677. Jadi $4-d_{\mathrm{U}}=2.2323,4-d_{\mathrm{L}}=2.3773$. Karena nilai DW (1.632) berada pada daerah antara $d_{\mathrm{L}}$ dan $d_{\mathrm{U}}$, maka hasilnya tidak dapat disimpulkan. Hal ini dapat ditolerasni karena data yang diuji merupakan data tahun, dimana tahun penelitian dijadikan diolah sebagai sampel penelitian.

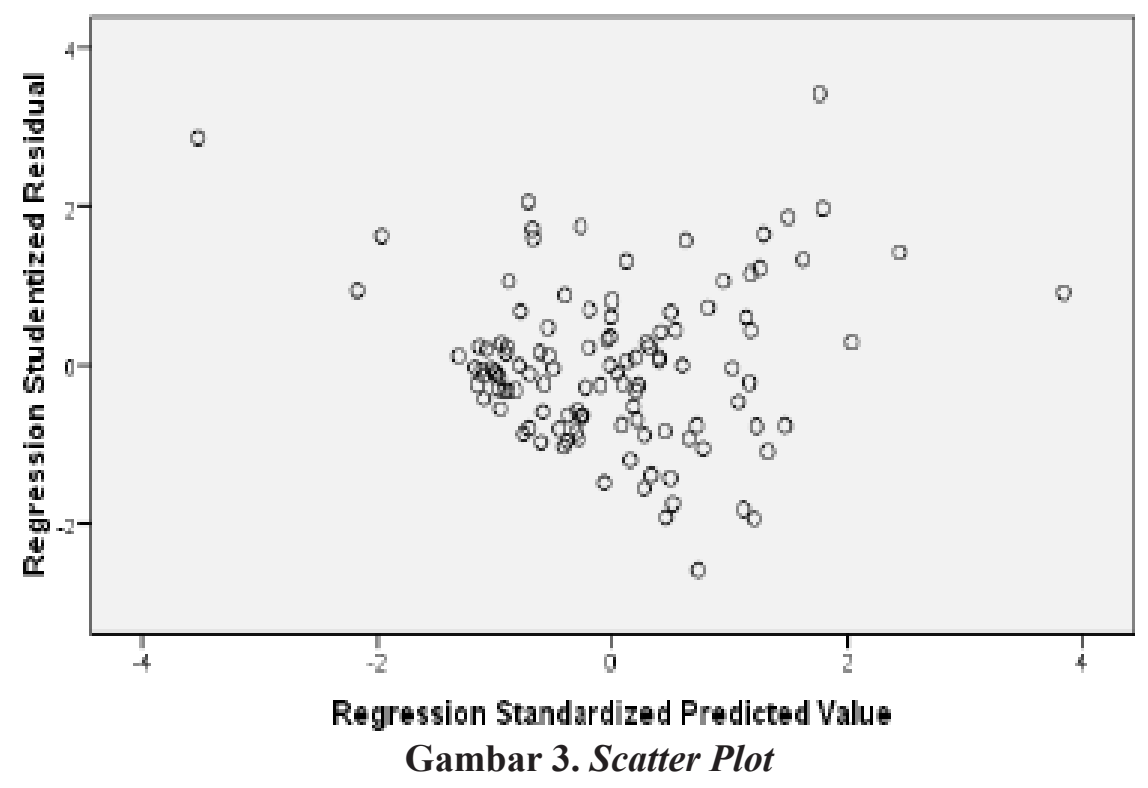

Dari gambar Scatterplot dapat diketahui bahwa tidak ada pola yang jelas, serta titik-titik menyebar di atas dan di -
Berdasarkan olah data dengan menggunakan SPSS, diperoleh hasil analisis regresi berganda pada Tabel 6 . 
Tabel 6. Hasil Pengujian Hipotesis

\begin{tabular}{lcccc}
\hline \multicolumn{1}{r}{ Keterangan } & B & Std. Error & t & Sig. \\
\hline CR & 0.000 & 0.031 & 0.003 & 0.997 \\
ROE & 8.444 & 0.786 & 10.737 & 0.000 \\
TATO & 0.108 & 0.177 & 0.609 & 0.544 \\
LnSIZE & 0.137 & 0.045 & 3.075 & 0.003 \\
Constant & -3.348 & 1.301 & & \\
R-Square & 0.612 & & & \\
Adjusted R-Square & 0.598 & & & \\
F-hitung & & & & \\
Sig. F & & & & \\
\hline
\end{tabular}

Berdasarkan tabel di atas, dapat disusun persamaan regresi linear berganda sebagai berikut:

PBV $=-\mathbf{3 . 3 4 8}+0.000 \mathrm{CR}+$ 8.444 ROE + 0.108 TATO + 0.137 LnSIZE

Penjelasan persamaan tersebut sebagai berikut:

a) Konstanta sebesar -3.348; artinya jika CR, ROE, TATO, dan LnSIZE nilainya 0, maka PBV nilainya sebesar -3.348 .

b) Koefisien regresi variabel CR sebesar 0.000; artinya jika CR mengalami kenaikan 1 satuan, maka PBV akan mengalami kenaikan sebesar 0.000 satuan.

c) Koefisien regresi variabel ROE sebesar 8.444; artinya jika ROE mengalami kenaikan 1 satuan, maka PBV akan mengalami peningkatan sebesar 8.444 satuan.

d) Koefisien regresi variabel TATO sebesar 0.108 ; artinya jika TATO mengalami kenaikan 1 satuan, maka PBV akan mengalami kenaikan sebesar 0.108 satuan.

e) Koefisien regresi variabel LnSIZE sebesar 0.137 ; artinya jika LnSIZE mengalami kenaikan 1 satuan, makaPBV akan mengalami peningkatan sebesar 0.137 satuan.

Dari tabel di atas, Nilai $\mathrm{F}_{\text {hitung }}$ adalah sebesar 43.040. Sedangkan nilai $F_{\text {tabel }}$ dapat dilihat pada tabel statistik F (pada taraf signifikansi $\alpha=5 \%$ dan derajat bebas $\mathrm{db}_{1}=\mathrm{k}$ dan $\left.\mathrm{db}_{2}=\mathrm{n}-\mathrm{k}-1\right)$, atau $\mathrm{db}_{1}=4$ dan $\mathrm{db}_{2}=114-4-1=109$. Diperoleh nilai $\mathrm{F}$ tabel $=2.455$.

Karena nilai $\mathrm{F}_{\text {hitung }}$ lebih besar daripada $\mathrm{F}_{\text {tabel }}$
$(43.040>2.455)$ maka dapat disimpulkan bahwa semua variabel independen (CR, ROE, TATO, dan LnSIZE) secara bersama-sama berpengaruh signifikan terhadap variabel dependen PBV. Nilai $\mathrm{t}_{\text {tabel }}$ dapat dilihat pada tabel statistik $\mathrm{t}$ (pada taraf signifikansi $\alpha=5 \%: 2=0.025$ (uji 2 sisi) dan derajat bebas $\mathrm{db}=\mathrm{n}-\mathrm{k}-1$, atau $\mathrm{db}=114-4-1=$ 109. Diperoleh nilai $\mathrm{t}_{\text {tabel }}$ sebesar 1.982 .

Dari hasil uji $t$ dapat disimpulkan sebagai berikut:

1. Variabel ROE berpengaruh secara signifikan terhadap variabel PBV. Hal ini disebabkan oleh $\mathrm{t}_{\text {hitung }}>\mathrm{t}_{\text {tabel }}(10.737>1.982)$.

2. Variabel LnSIZE berpengaruh secara signifikan terhadap variabel PBV. Hal ini disebabkan oleh $t_{\text {hitung }}>t_{\text {tabel }}(3.075>1.982)$.

3. Variabel CR dan TATO tidak berpengaruh secara signifikan terhadap variabel PBV. CR memiliki $\mathrm{t}_{\text {hitung }}$ sebesar 0.003 dan TATO memiliki $t_{\text {hitung }}$ sebesar 0.609 , yaitu lebih kecil daripada $\mathrm{t}_{\text {tabel }}(1.982)$.

Dari tabel di atas dapat diketahui nilai Adjusted $R$ Square (Adjusted $R^{2}$ ) sebesar 0.598 (59.8\%). Artinya, kontribusi pengaruh semua variabel independen (CR, ROE, TATO, dan LnSIZE) terhadap variabel dependen PBV adalah sebesar $59.8 \%$. Sedangkan sisanya sebesar $40.2 \%$ dipengaruhi oleh variabel lain yang tidak diteliti.

\section{Pengaruh Current ratio (CR) terhadap Price to book value (PBV)}

Hipotesis pertama disebutkan bahwa 
Current ratio (CR) berpengaruh secara signifikan terhadap Price to book value (PBV). Berdasarkan hasil uji t yang dilakukan, hipotesis pertama yang menyatakan bahwa Current ratio (CR) memiliki pengaruh secara signifikan terhadap Price to book value $(P B V)$ ditolak. Artinya, Current ratio (CR) tidak berpengaruh secara signifikan terhadap Price to book value (PBV).

Current ratio (CR) merupakan satu rasio likuiditas perusahaan. Current ratio (Rasio lancar) bertujuan untuk mengukur kemampuan perusahaan dalam membayar kewajiban jangka pendek atau utang yang segera jatuh tempo. Dengan kata lain, seberapa banyak aktiva lancar yang tersedia untuk menutupi kewajiban jangka pendek yang segera jatuh tempo. Secara teoretis, semakin tinggi current ratio (CR) suatu perusahaan berarti semakin kecil risiko kegagalan perusahaan dalam memenuhi kewajiban jangka pendeknya. Akibatnya risiko yang akan ditanggung pemegang saham juga semakin kecil (Robert Ang, 1997).

Tidak terbuktinya hipotesis ini kemungkinan disebabkan bahwa investor tidak menjadikan faktor likuiditas sebagai faktor yang memengaruhi minat investor pada suatu saham pada tahun periode penelitian, sehingga apakah suatu perusahaan memiliki likuiditas tinggi atau memiliki likuiditas rendah, maka nilai price to book value $(P B V)$ akan ditentukan oleh faktor lain selain current ratio. Misalkan faktor profitabilitas, sebagaimana akan dijelaskan di pembahasan hipotesis kedua. Likuiditas yang tinggi belum tentu memiliki profitabilitas yang tinggi. Likuiditas yang tinggi dapat pula menunjukkan ketidakmampuan perusahaan untuk memanfaatkan dana yang tersedia yang bisa menghasilkan keuntungan bagi perusahaan. Sebaliknya, likuiditas yang rendah bisa saja memiliki profitabilitas yang tinggi. Hal ini menunjukkan bahwa perusahaan efisien mengelola dana jangka pendeknya sehingga menghasilkan laba. Investor tentunya berharap untuk mendapatkan return dari modal yang ditanamkan termasuk dividen. Oleh karena itu, investor kemungkinan besar akan lebih memerhatikan faktor lain, seperti tingkat profitabilitas perusahaan, karena kemungkinan untuk mendapatkan dividen, dibandingkan tingkat likuiditas, yang dalam hal ini direpresentasikan dengan current ratio. Dalam penelitian ini dapat disimpulkan bahwa Current ratio (CR) perusahaan Consumer goods secara parsial tidah berpengaruh secara signifikan terhadap terhadap Price to book value (PBV). Hal ini sejalan dengan hasil penelitian Widigdo (2010) yang menyatakan bahwa Current ratio (CR) tidak berpengaruh secara signifikan terhadap Price to book value $(P B V)$.

\section{Pengaruh Return on equity terhadap Price to book value (PBV)}

Hipotesis kedua disebutkan bahwa Return on equity ( $R O E$ ) berpengaruh signifikan terhadap Price to book value (PBV). Berdasarkan hasil uji $\mathrm{t}$ yang dilakukan, hipotesis kedua yang menyatakan bahwa Return on equity (ROE) memiliki pengaruh secara signifikan terhadap Price to book value $(P B V)$ diterima. Artinya, Return on equity (ROE) berpengaruh signifikan terhadap Price to book value (PBV). Return on equity (ROE) merupakan salah satu rasio profitabilitas, yaitu rasio untuk mengukur laba bersih sesudah pajak dengan modal sendiri. Rasio ini menunjukkan efektifitas perusahaan dalam menghasilkan keuntungan dibandingkan dengan modal sendiri. Rasio ini menunjukkan efisiensi penggunaan modal sendiri.

Semakin tinggi Return on equity ( $R O E$ ) suatu perusahaan menunjukkan bahwa perusahaan semakin efisien dalam menghasilkan keuntungan atau laba. Profitabilitas merupakan salah satu informasi yang penting dan menjadi daya tarik bagi investor untuk menanamkan modalnya. Kinerja profitabilitas yang semakin baik akan memberikan sinyal atau perspektif yang positif kepada investor atau calon investor sebagai acuan untuk memprediksi profitabilitas di masa mendatang. Hal ini dapat menjadi dorongan bagi investor atau calon investor untuk menanamkan modalnya pada perusahaan dengan kinerja profitabilitas yang baik. Semakin tinggi dana yang ditanamkan oleh investor cenderung akan 
meningkatkan harga saham, dan dengan demikian meningkatkan Price to book value (PBV). Dalam penelitian ini dapat disimpulkan bahwa Return on equity (ROE) perusahaan Consumer goods secara parsial berpengaruh secara signifikan terhadap terhadap Price to book value (PBV).

Hasil penelitian ini mendukung hasil penelitian Eva Eko Hidayati (2010) dan Ni Gusti Putu Wirawati (2008) yang menyatakan bahwa ROE secara individual memiliki hubungan yang positif dan berpengaruh signifikan terhadap PBV. Hal ini sejalan dengan hasil penelitian Widigdo (2010) dan Puspita (2011). Hal ini juga sejalan dengan pendapat dari Robert Ang (1997) yang menyatakan bahwa keuntungan perusahaan yang semakin meningkat memberikan tanda bahwa kekuatan operasional dan keuangan perusahaan semakin membaik, sehingga memberikan pengaruh positif terhadap ekuitas.

\section{Return on equity (ROE) berpengaruh signifikan terhadap Price to book value (PBV)}

Hipotesis ketiga disebutkan bahwa Total assets turnover (TATO) berpengaruh secara signifikan terhadap Price to book value (PBV). Berdasarkan hasil uji t yang dilakukan, hipotesis ketiga yang menyatakan bahwa Total assets turnover (TATO) memiliki pengaruh secara signifikan terhadap Price to book value (PBV) ditolak. Artinya, Total assets turnover (TATO) tidak berpengaruh secara signifikan terhadap Price to book value (PBV). Total assets turnover (TATO) adalah salah satu rasio aktivitas, yaitu rasio yang menunjukkan kemampuan serta efisiensi perusahaan dalam memanfaatkan aktiva yang dimilikinya atau perputaran aktivaaktiva tersebut. Total assets turnover (TATO) digunakan untuk mengukur seberapa efisiennya seluruh aktiva perusahaan dimanfaatkan dalam menunjang kegiatan penjualan (Robert Ang, 1997). Hal ini berarti semakin tinggi rasio TATO maka semakin efisien suatu perusahaan dalam memanfaatkan aktiva yang dimilikinya.

Analisis terkait penyebab Total assets turnover (TATO) tidak berpengaruh secara signifikan terhadap Price to book value (PBV) adalah bahwa investor tidak menjadikan faktor manajemen aktiva sebagai faktor yang memengaruhi minat investor suatu saham pada periode penelitian. Total assets turnover (TATO) yang tinggi atau rendah belum tentu menjadi pertimbangan investor untuk memilih saham suatu perusahaan, sehingga Price to book value (PBV) ditentukan oleh faktor di luar Total assets turnover (TATO), misalkan faktor profitabilitas. Dalam penelitian ini dapat disimpulkan bahwa Total assets turnover (TATO) perusahaan Consumer goods secara parsial tidah berpengaruh secara signifikan terhadap terhadap Price to book value $(P B V)$. Hal ini sejalan dengan hasil penelitian Widigdo (2010) yang menyatakan bahwa Total assets turnover (TATO) tidak berpengaruh secara signifikan terhadap price to book value (PBV).

\section{Pengaruh Size terhadap Price to book value (PBV).}

Hipotesis keempat disebutkan bahwa Size berpengaruh secara signifikan terhadap Price to book value $(P B V)$. Berdasarkan hasil uji t yang dilakukan, hipotesis keempat yang menyatakan bahwa Size memiliki pengaruh secara signifikan terhadap Price to book value (PBV) diterima. Artinya, Size berpengaruh secara signifikan terhadap Price to book value (PBV). Assets atau aktiva adalah faktor yang penting dalam menunjang kegiatan operasi perusahaan untuk menghasilkan produk atau jasa dalam rangka penjualan. Assets harus dapat dikelola dengan baik sehingga dapat menghasilkan laba. Hasil penelitian ini menunjukkan bahwa nilai assets selama periode penelitian memberikan sinyal yang positif bagi investor karena semakin tinggi nilai assets menunjukkan kecenderungan tingkat profitabilitas yang meningkat pula.

Dalam penelitian ini dapat disimpulkan bahwa Size perusahaan Consumer goods secara parsial berpengaruh secara signifikan terhadap terhadap Price to book value $(P B V)$. Hasil penelitian ini sejalan dengan hasil penelitian Eva Eko Hidayati (2010) dan Soliha dan Taswan (2002) berkaitan dengan Size perusahaan. Hasil penelitiannya menunjukkan bahwa Size secara 
individual berpengaruh signifikan terhadap PBV.

\section{Pengaruh Current ratio (CR), Return on equity (ROE), Total assets turnover (TATO), dan Size terhadap Price to book value (PBV)}

Hipotesis kelima disebutkan bahwa Current ratio, Return on equity, Total assets turnover, dan Size secara simultan berpengaruh secara signifikan terhadap Price to book value $(P B V)$. Berdasarkan hasil uji F dapat disimpulkan bahwa hipotesis kelima yang menyatakan bahwa semua variabel independen (CR, ROE, TATO, dan LnSIZE) secara bersamasama berpengaruh signifikan terhadap variabel dependen PBV diterima. Artinya, Current ratio (CR), Return on equity (ROE), Total assets turnover (TATO), dan Size secara simultan berpengaruh signifikan terhadap Price to book value (PBV).

Hasil penelitian ini menunjukkan bahwa faktor fundamental perusahaan yang berasal dari laporan keuangan dan direpresentasikan oleh Current ratio (CR), Return on equity (ROE), Total assets turnover (TATO), dan Size secara bersama-sama memberikan sinyal yang positif bagi investor untuk memprediksi kinerja perusahaan di masa mendatang sehingga menjadi pertimbangan investor untuk memilih saham suatu perusahaan. Semakin baik kinerja perusahaan, investor semakin berminat untuk menanamkan modalnya dalam suatu perusahaan. Sampai level tertentu, hal ini akan meningkatkan harga saham dan berakibat meningkatnya Price to book value (PBV). Dalam penelitian ini dapat disimpulkan bahwa Current ratio (CR), Return on equity (ROE), Total assets turnover (TATO), dan Size perusahaan Consumer goods secara bersama-sama berpengaruh secara signifikan terhadap terhadap Price to book value (PBV).

\section{Kesimpulan, Keterbatasan dan Implikasi Hasil Penelitian}

Hasil pengujian hipotesis dengan menggunakan analisis regresi berganda menunjukkan bahwa:
1. Current ratio (CR) secara parsial tidak memiliki pengaruh signifikan terhadap Price to book value (PBV).

2. Return on equity (ROE) secara parsial memiliki pengaruh yang signifikan terhadap Price to book value (PBV).

3. Total assets turnover (TATO) secara parsial tidak memiliki pengaruh signifikan terhadap Price to book value (PBV).

4. Size secara parsial memiliki pengaruh signifikan terhadap Price to book value (PBV).

Penelitian ini mempunyai keterbatasan, terutama dalam hal:

1. Hasil penelitian ini menunjukkan $59.8 \%$ pengaruh variabel independen dalam memengaruhi variabel dependen dan sisanya sebesar $40.2 \%$ dipengaruhi oleh faktorfaktor lain yang tidak dimasukkan dalam model sehingga masih banyak variabel yang berpengaruh namun tidak dimasukkan dalam model ini.

2. Penelitian ini terbatas pada saham yang termasuk dalam industri Consumer goods yang terdaftar di Bursa Efek Indonesia sehingga masih banyak perusahaan emiten lainnya yang belum masuk dalam penelitian ini.

3. Penelitian ini hanya mencakup periode penelitian selama 6 tahun yakni mulai tahun 2006 sampai dengan tahun 2011 sehingga penelitian masih dalam waktu yang terbatas dan belum dapat digeneralisir untuk periode yang lebih panjang.

Pada penelitian yang akan datang terdapat beberapa hal yang perlu diperhatikan, diantara adalah sebagai berikut:

1. Dalam penelitian mendatang perlu menambahkan menambah variabel fundamental lainnya dan juga variabel teknikal, seperti variabel ekonomi makro dan yang lainnya sebagai variabel independen, karena sangat dimungkinkan variabel lain yang tidak dimasukkan dalam penelitian ini berpengaruh kuat terhadap Price to book 
value $(P B V)$.

2. Untuk penelitian selanjutnya sebaiknya menggunakan sampel yang berbeda dan tidak terbatas pada satu sektor industri saja, dengan demikian diharapkan akan memberikan kontribusi informasi yang lebih baik dan akurat untuk penelitian mendatang.

3. Menambahkan rentang waktu yang lebih panjang sehingga nantinya diharapkan hasil yang diperoleh akan lebih dapat digeneralisasikan dan untuk memperluas penelitian serta menghasilkan analisis yang lebih baik.

Secara simultan variable-variabel independen (Current ratio, Return on equity, Total assets turnover, dan Size) berpengaruh signifikan terhadap Price to book value (PBV) pada perusahaan Consumer goods yang terdaftar di Bursa Efek Indonesia selama periode 2006 sampai dengan 2011. Hasil penelitian ini menunjukkan bahwa Return on equity (ROE) dan Size perusahaan berpengaruh secara signifikan terhadap Price to book value (PBV) pada perusahaan Consumer goods yang terdaftar di Bursa Efek Indonesia (BEI) selama periode penelitian dari tahun 2006 sampai dengan tahun 2011. Return on equity (ROE) adalah salah satu rasio profitabilitas. Semakin tinggi tingkat profitabilitas yang dihasilkan dari waktu ke waktu, hal ini menunjukkan kinerja perusahaan yang semakin baik. Hal ini akan menjadi daya tarik bagi investor untuk menginvestasikan dananya pada perusahaan tersebut sehingga dapat meningkatkan permintaan atas saham perusahaan tersebut. Kenaikan permintaan tersebut cenderung meningkatkan harga saham, sehingga berakibat pula meningkatnya Price to book value (PBV).

Hasil penelitian ini juga menunjukkan bahwa Size perusahaan berpengaruh secara signifikan terhadap Price to book value (PBV). Semakin besar assets yang dimiliki perusahaan, pihak manajemen lebih leluasa dalam mempergunakan asset yang ada di perusahaan tersebut untuk kegiatan operasi yang produktif yang dapat menghasilkan keuntungan bagi perusahaan. Hal ini juga menjadi daya tarik investor untuk menanamkan modalnya di perusahaan tersebut sehingga dapat meningkatkan harga saham. Hal ini tentu dapat meningkatkan Price to book value (PBV).

Oleh karena itu, manajemen perlu memperhatikan faktor kebijakan profitabilitas dan assets perusahaan untuk meningkatkan nilai perusahaan yang dalam hal ini diwakili oleh Price to book value (PBV). Pada tingkat tertentu, semakin tinggi PBV menunjukkan sinyal yang positif yakni menunjukkan kinerja perusahaan yang semakin baik.

\section{DAFTAR PUSTAKA}

Ekayana. (2007) Analisis pengaruh insider ownership, kebijakan hutang, profitabilitas dan ukuran perusahaan terhadap nilai perusahaan (Studi empiris terhadap perusahaan manufaktur yang terdaftar di Bursa Efek Jakarta tahun 2001-2005), ASET Vol.9 Nomer 2 Agustus 2007.

Hidayati, E.E. (2010). Analisis Pengaruh DER, DPR, ROE dan SIZE terhadap PBV Perusahaan Manufaktur yang Listing di BEI Periode 2005-2007. Tesis, Universitas Diponegoro, Semarang.

Masdar Mas'ud. (2008). Analisis FaktorFaktor yang Memengaruhi Struktur Modal dan Hubungannya terhadap Nilai Perusahaan. Manajemen Dan Bisnis Volume 7, Nomor 1, Maret 2008.

Puspita, Fira. (2009). Analisis Faktor-Faktoryang Mempengaruhi Kebijakan Dividend Payout Ratio: Studi Kasus pada Perusahaan yang terdaftar di Bursa Efek Indonesia Periode 2005-2007. Tesis, Universitas Diponegoro, Semarang.

Puspita, Novita Santi. (2011). Analisis Pengaruh Struktur Modal, Pertumbuhan Perusahaan, Ukuran Perusahaan, dan Profitabilitas terhadap Nilai Perusahaan pada Perusahaan Manufaktur yang Terdaftar di Bursa Efek Indonesia Periode 2007-2009: Studi Kasus pada Sektor Industri Food and Beverages. Skripsi, Fakultas Ekonomi Universitas Diponegoro, Semarang.

Putra, T.P., Chabachib, M., Haryanto, M., dan 
Pangestuti, I.R.D. (2008). Pengaruh Kinerja Keuangan dan Beta Saham terhadap Price to Book Value: Studi pada Perusahaan Real Estate dan Property yang Listed di BEI Periode Tahun 2004-2006. Skripsi, Universitas Diponegoro.

Saputra, D.A. (2010). Pengaruh Return on Equity (ROE) dan Deviden Payout Ratio (DPR) terhadap Price to Book Value (PBV) pada Perusahaan Perbankan yang Go Public di PT Bursa Efek Indonesia. Skripsi, Universitas Pembangunan Nasional "Veteran", Jawa Timur.

Sidharta, U., Anto, Y., \& Budhi, S. (1998). Kaitan antara Rasio Price/Book Value dan Imbal Balik Hasil Saham pada Bursa Efek Jakarta. Jurnal Riset Akuntansi Indonesia Vol.1 No.1.

Soliha, E,. \& Taswan. (2002). Pengaruh Kebijakan Hutang terhadap Nilai Perusahaan SertaBeberapaFaktoryang Memengaruhinya. Jurnal Bisnis dan Ekonomi.

Subalno, (2009). Analisis Pengaruh Faktor Fundamental dan Kondisi Ekonomi terhadap Return Saham. Tesis, Universitas Diponegoro, Semarang.

Taswan. (2003). Analisis Pengaruh Insider Ownership, Kebijakan Hutang dan Deviden Terhadap Nilai Perusahaan serta FaktorFaktor yang Memengaruhinya. Jurnal Bisnis Dan Ekonomi, Vol.10 No.2 September 2003.

Widigdo, (2010). Faktor yang Mempengaruhi Price to Book Value Perusahaan Publik di Bursa Efek Indonesia, Tesis, Universitas Pembangunan Nasional Veteran, Jakarta.

Wild, John J., Subramanyam, K.R., and Halsey, Robert F. (2008). Financial Statement Analysis. New York USA: McGraw-Hill Internaltional Edition, 8th edition

Wirawati, Ni Gusti Putu., (2008). Pengaruh Faktor Fundamental Perusahaan terhadap Price to Book Value dalam Penilaian Saham di Bursa Efek Jakarta dalam Kondisi Krisis Moneter, Buletin Studi Ekonomi Volume 13 Nomor 1. 